\title{
Military Security within the Framework of Security Studies: Research Results
}

\author{
Ryszard Szpyra*
}

\begin{abstract}
The present article is based on a number of key assumptions as well as a conceptual system of military security, which is anchored in the theoretical system of security studies. Since these two disciplines are relatively young, there is a need to analyze them for the purpose of determining the basic theoretical apparatus in the field of security studies. This article presents an original definition and description of the fundamental nature of security as well as a general description of military security. It includes the vital domain of the subject's own activity leading to the maintenance of the proper level of security. The paper contains original definitions of such basic categories as security, state security and military security. Indeed, much of the content is based on theories used in previous research, but these have served merely as "bricks" that are used to fill in the already existing theoretical structure. Thus, through a specific redesign, a structure compatible with the basic tenets of security studies has been devised, also taking into account recent results of other sciences that cover military affairs.
\end{abstract}

Keywords: Security, state security, military security.

\section{Introduction}

Despite a number of profound changes that have taken place in the international situation, a military force is still one of the most important instruments of international policies carried out by states to protect their vital as well as less important interests. Thus, military power has a significant impact on countries' possibility of uninterrupted existence and development, which directly shapes their security.

In previous studies on military questions, focus was directed on various aspects of the existence and use of armed forces. Strategic studies paid most attention to general concepts and methods of using military means in achieving policy objectives. Earlier military science, in contrast, understood mainly as the art of war, investigated and sought optimal rational "technologies" of fighting, methods of application of force that would ensure a higher probability of victory. More recently, security studies have arisen, and it has become apparent that one of the critical areas of security is the military domain. Very quickly, appropriate adaptations have been made and the results of the research done in these fields have been introduced as the body of military security studies. Undoubtedly, an important part of the acquis communautaire can also be the content of the acquis of military security studies, but it is also necessary to introduce and describe the structure derived from the basic assumptions of the general theory of security studies. This forms the inspiration and purpose of the following study.

Professor Ryszard Szpyra is Head of Doctoral Studies at the Institute of State Security, National Security Faculty, National Defense University in Warsaw, Poland. 


\section{Origin and understanding of security}

The fundamental problem of security studies is its multi-dimensional definition. In terms of research, the lack of a clear definition of security can cause the blurring of the boundaries between science and security-related disciplines. These include international relations, political or military science - each operating with a different conceptual apparatus - and perspective and research methodology. Because of the numerous definitions of security, when focusing on its different aspects, many issues arise for security studies.

Security studies - a sub-discipline of international relations - emerged as a scientific discipline after the Second World War. During the course of developments of the Cold War era and later, the field underwent various changes. In Poland, security studies emerged primarily from the now-defunct military science by expanding the field of research far beyond military security.

The field of security studies is now located at the intersection of several disciplines, even though the field of international relations seems to dominate its overall perception. The field is based on interdisciplinary research and is characterized by a multiplicity of theoretical and epistemological perspectives, focusing attention mainly on the physical dimension, namely, structural and symbolic force and violence. In this respect, the most dynamically developing branch of research in this discipline deals with analyzing the links between security, culture and the identity of individuals and societies. ${ }^{1}$

A review of the schools of thought and the definitions of security shows that they are highly diverse and reflect the fundamental nature of security in different ways. Thus, it was decided to propose in this study a definition of security that is designed for consistency, whereby an attempt will be made to redefine the concept of security. This in turn will provide the basis for reconsidering the concept of military security. Providing a definition is an attempt to synthesize the existing acquis rather than to create a whole new category.

It is necessary to start basic definition considerations with a semantic analysis. In English, there are at least four words related to security. They are: safe, safety, secure, security, as follows:

- Safe means, among other things: not threatened by harm (not at risk of injury), protected from danger (protected against threats), not hurt, unharmed (undamaged) ${ }^{2}$

- $\quad$ Safety includes: the state of being safe, free from threats, danger, harm or risk;

- Secure includes: safe, protected against danger or risk, having no doubt, fear or anxiety as a result of effort; ${ }^{3}$

- Security includes: the state of being secure, a protection against, something which protects or makes secure. ${ }^{4}$

1 Paul D. Williams, ed., Security Studies: An Introduction (New York: Routledge, 2009), 502504.

2 Longman Dictionary of Contemporary English. New Edition (Warsaw: PWN, 1990), 921.

3 Longman Dictionary, 944. 
Language norms relating to the native language of the author are also very important. In Polish, "safe" means something that is not in danger, not threatened, not jeopardizing anything or that protects from danger. ${ }^{5}$ Security is the state of a lack of threat, of confidence, of personal safety, of safety of the country and its citizens; a sense of security; to ensure the safety of anyone; to watch over someone's safety; not to violate someone's safety. ${ }^{6}$ It is important to also understand the word "state," which means all the circumstances and conditions in which someone or something can be found at any given time, level, quantity of something, the situation or a position.

A semantic analysis of words directly related to security leads to the following conclusions:

- Someone (something), that is, a given entity can be in a safe or a dangerous situation, hence in a particular state of the situation;

- Someone, that is, a given entity can feel secure or insecure, which is also referred to as a particular state in a given situation;

- Someone (something) or a specific instrument can provide (guarantee, protect) the security of an entity;

- Someone (something) may endanger someone (something) and is therefore a specific entity that constitutes the threat (Fig. 1).

One of the authors who quite early on, considering Polish conditions, attempted to define security is Ryszard Zięba. In one of his studies, he points out that security, derived from the Latin sine cura (securitas), is a state of confidence, peace, security and the feeling of the absence of risk and protection against it. ${ }^{7}$

The author notes that ${ }^{8}$ in the social sciences, security, in its most general sense, includes the satisfaction of such needs as existence, survival, whole identity (identity), independence, peace, possession and self-development. Otherwise, ${ }^{9}$ the study assumes that security can be defined as the certainty of the existence and survival as well as the functioning and development of the subject. ${ }^{10}$ Confidence, which depends not only on

4 Longman Dictionary, 944.

5 Uniwersalny stownik języka polskiego A-J (Warsaw: PNW, 2006), 235.

6 Ibid.

7 Ryszard Zięba, Instytucjonalizacja bezpieczeństwa europejskiego. Koncepcje - struktury funkcjonowanie (Warsaw: Scholar, 1999), 27.

Zięba, Instytucjonalizacja, 27.

9 Ryszard Zięba, "Pojęcie i istota bezpieczeństwa międzynarodowego," Bezpieczeństwo międzynarodowe po zimnej wojnie, ed. R. Zięba (Warsaw: WaiP, 2008), 16.

10 "Subject" is a category that has been chosen to embrace the definitions of both state and nonstate actors that take part in creating the security environment. The term originates from philosophy; Nina Power describes it as follows: "the noun 'subject' refers to a legal or political person/collective and to a perceiving or cognising self..." and "It is this conception of a collectivized, political subject that haunts all attempts to reduce the philosophical notion of the subject to an individuated consciousness or a primarily moral being." Cf. Nina Power, "Philosophy's Subjects," PARRHESIA: A Journal of Critical Philosophy 3 (2007), 56 and 69; www.parrhesiajournal.org/past.html. 


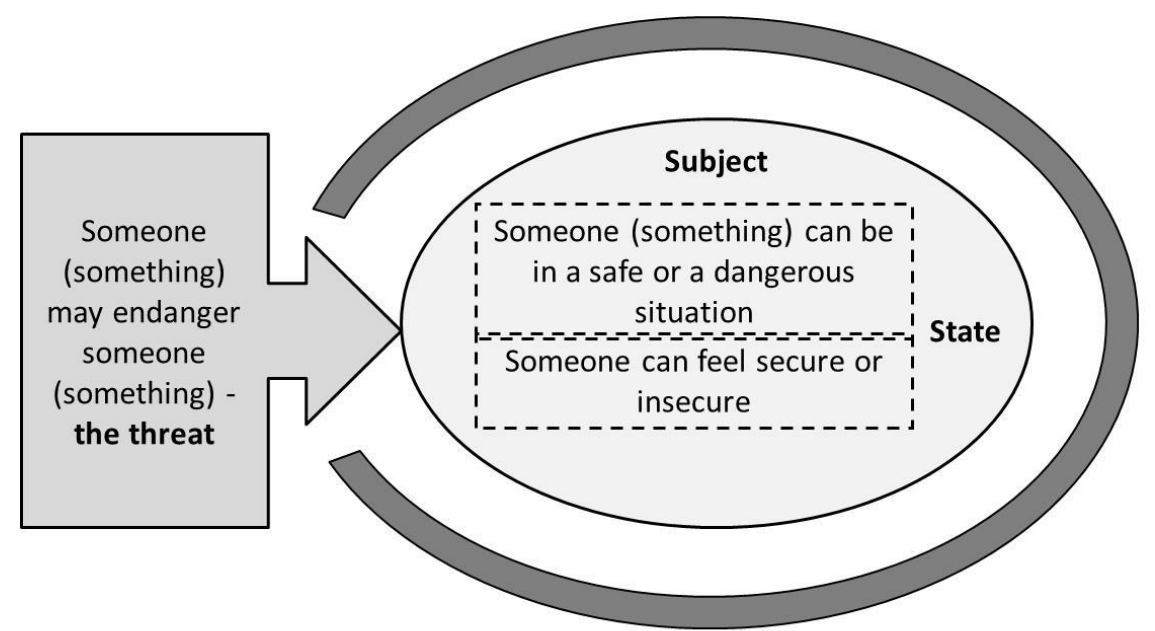

Someone (something) can provide (guarantee, protect) the security of an entity - security instrument

Figure 1: The field of security resulting from the semantic analysis.

the lack of risk (the absence or elimination thereof) is also the result of a creative activity of a subject and is variable over time or has the nature of a social process.

Bearing these considerations in mind, the following conclusions can be drawn. In the face of threats, to achieve the desired level of security it is necessary to:

- Have situational awareness;

- Strive to change the situation in which threats exist and neutralize them.

To achieve this, one must take two basic types of action, namely, those needed for:

- Obtaining and maintaining situational awareness;

- Neutralizing threats.

In conclusion, we can say that the part of the overall security model that refers to the activity of a security subject is comprised of two basic sub-elements:

- Actions necessary to achieve situational awareness;

- Actions needed to neutralize threats.

The findings also held that security is very much linked to the possibility of continuity and development of the subject. The basic condition for both the existence and the development of any subject of security is appropriately fulfilling its needs, i.e. realizing different types of supply.

Threats. The reflections on the essence of security lead to the conclusion that it concerns the survival and development of a security subject. These, in turn, are directly de- 
pendent on the satisfaction of the needs of this subject. In this respect, at one end of the spectrum we meet needs that ensure the subject's survival and development. The other end of the spectrum is the inability to satisfy any need, which prevents the existence of the security subject. The ability to meet the needs of the subject is, therefore, a key requirement for the subject's continuity and development.

This, however, is only one possibility, because on the way to implementing this requirement many current or potential obstacles exist. The reasons may be different. One of the most important is intentional actions of others. For the purposes of this model, real and potential obstacles that may prevent meeting the needs of the subject in question are called security threats. In this situation, the threat will be understood as objectively existing and as potential obstacles that prevent any form of meeting the needs of the security subject.

Individual activity. Both the semantic analysis (someone/something - a specific instrument can provide/guarantee/protect the security of the entity) and the definition of security studies by different authors, as well as the assumptions of other theories (e.g. praxeology) show that one of the main factors affecting the level of security is the individual activity of the security subject. Based on the foregoing considerations, it can be concluded that threats are the main obstacle to achieving an acceptable level of security and, in practice, the desired level of supply of the subject's needs. For this reason, the activity of the security subject should be aimed mainly at countering threats or neutralizing obstacles, in order to meet the needs of the subject (Fig. 2). The main objective of this activity is to create the conditions for seamless fulfillment of the needs of the security subject or ensuring its continuity and development.

During the discussion on the nature of security, it has also been found that situational awareness is the basis for any activity, as well as a part of the fundamental nature of security. This awareness does not arise by itself, but is the result of purposeful activity and, therefore, the subject's own activity must be composed of two streams: one aimed at achieving and maintaining situational awareness at the desired level, the second aimed at neutralizing threats.

The aforementioned observation does not mean that a threat can be neutralized only by the activity of the security subject. It can happen that neutralization is dependent on other factors. However, especially when the security subject is a country, its own activity must be the basis of building the desired state of security.

As a result we may consider that:

In social sciences, security is a state (condition) variable in time that determines the ability to meet the social needs of existence and development of the subject despite the presence of real or potential threats. It also includes the awareness of the condition in question as well as all activities aimed at achieving the desired level of security.

National security is a state (condition) variable in time that determines the ability to meet the social needs of existence and development of the nation despite the presence of real or potential threats. It also includes the awareness of the condition in question as well as all activities aimed at achieving the desired level of security. 




Figure 2: A simplified model of security.

With the above understanding of security, however, the level of security at any given moment is unclear. We only know that it is a state (condition), but we do not know what it is like. Therefore, to determine the level of security, one needs additional categories that describe the levels of this state and tools to measure them.

\section{Outline of the concept of military security}

Military questions have been debated since the dawn of literature and scientific activity. These considerations, however, were suggested and developed from different perspectives and for different purposes. Some creative activity concerning military matters was dedicated to fighting technology. The authors dealing with this problem mostly sought to identify regularities governing armed struggle in order to make it more effective. In the Polish cultural area, this was the part of military science called the art of war.

Another group of researchers have studied and described armed struggle in the broader context of international relations. These authors have left combat fighting technology issues for military researchers, focusing their own scholarly activities on the political circumstances of maintaining and using military force in international state policies.

The second half of the twentieth century gave birth to another research approach based on analyzing the security of a subject and seeking ways of ensuring it. As part of this approach, considerations relating to the sphere of military security also appeared. 
These considerations can be divided into domestic and foreign ones. Among the former, the considerations developed at the National Defense University are predominant.

In various studies, the term "military security" usually denotes the ability of a state to defend and/or deter military aggression. Alternatively, "military security" refers to the ability of the state to enforce its policy decisions using military force. The term "military security" is considered synonymous with "security" in a number of ways.

The Dictionary of Military and Associated Terms defines "security" as a condition that results from protective measures being established and maintained, whereby a condition of inviolability from hostile acts or influences is ensured. ${ }^{11}$ This is, traditionally, the earliest recognized form of national security. ${ }^{12}$ Today, however, the scope of military security has expanded from conventional forms of conflict between nationstates to the struggle between states and non-state actors.

Polish authors have made numerous attempts to define military security, but despite reaching many important conclusions connected to the fundamental nature of military security, these definitions are not wide enough to be included in the theory of security. However, this definition of military security should be derived from some generally accepted interpretations of security. Also, in the international literature on this topic, researchers have not focused enough on defining the phenomenon, concentrating rather on merely describing its different aspects. Thus, it is necessary to try to develop a definition of military security to can meet these needs.

\section{Elements of the Military Security Model}

Military security is a category related mainly to the state (country) as its subject. As such, the greatest achievements in this field have been in the area of political science, whereas the field of international relations has studied and gathered knowledge about the relationship between states. In accordance with theories developed by these disciplines, the military security of a state is mostly derived from the existence of the subject: the state and the international environment surrounding it. It is also inextricably linked to the existence of the armed forces. These are the fundamental elements belonging to the category of neorealist theories of international politics associated with the survival of countries and their possibilities for growth.

The existence of security problems resulting from the efforts of countries to ensure their own security has a significant impact on military security. Countries, in fact, create increased insecurity between one another, because each country interprets its own actions as defensive and those of others as potentially threatening, regardless of the reasons for a particular action.

The sources of military threats should be seen within the characteristics of the international environment in which military power is one of the main instruments of states'

11 Department of Defense Dictionary of Military and Associated Terms. Joint Publication 1-02. (Washington, DC: DoD, 2012), 279.

12 Prabhakaran Paleri, National Security: Imperatives And Challenges (New Delhi: Tata McGraw-Hill, 2008), 521. 
international politics. This is mainly because military power is the only instrument capable of physically destroying elements of another state or of using effective forms of violence. This power, merely through its very existence a very effective tool of influence, creates a threat to the security of other countries. This threat is exacerbated by the existence of states whose international relations are based on dishonesty. At the current level of military technology development, rapid changes in power relations between states can take place. This opens the possibility for dishonest states to overcome other parties unfairly yet successfully. A state, aware of this fact when making alliances and signing agreements on arms control, exercises caution and attempts to actively ensure its own security. Military strength, already by its very existence, creates a threat to the security of other states. This is a fact that many authors and a number of official international documents ignore.

Admittedly, there is a general awareness today that the use of force to resolve international disputes is prohibited by international law. There are exceptions to this prohibition. Military power can be used for collective or self-defense and with the consent of the UN Security Council. Therefore, each country can legally maintain armed forces for defense.

It is easy to see that this approach results from the realist school of thought in international relations, which, as is well known, is quite pessimistic. There is a more optimistic approach based on liberalism and constructivism. However, as in the methods of scenario planning, preparing for resistance in nefarious scenarios also means preparing for better scenarios. In international practice, the realist approach is still the most basic foundation for building national security strategy. Nonetheless, states generally oppose actions against military threats based on, for example, the concept of the balance of power. Theories of deterrence also have a wide application. Moreover, it should be noted that the sphere of security refers to the most dangerous consequences of threats. Military threat may, in fact, lead to a total or partial loss of sovereignty and territorial integrity, which is why states cannot accept excessively high risks.

To return to the main course of thought in this paper, from an analytical standpoint, a state typically categorizes other, potentially dangerous states based on three factors: capability, intent and circumstances. ${ }^{13}$

The term "capability" refers to the physical ability to wage warfare on a significant scale. Any sovereign entity, except perhaps the smallest ones, possesses such a capability. While to maintain the balance of power it is not necessary to cause serious harm to another country, nonetheless most countries should consider the possibility of direct threats coming from their neighbors. Also, countries with relatively long maritime borders must consider the fact that also countries other than their immediate neighbors may pose a threat to their territory. The situation is further complicated by the possibility of air strikes that can be carried out even by distant states.

"Intent," the second factor, refers to the degree of determination necessary for a country to be willing to initiate an attack. It is worth pausing to consider the problem of

13 Frederick H. Hartmann, The Relations of Nations (New York: Macmillan, 1978), 259-261. 




Figure 3: The three main components of military security.

defense and especially its definition. Some understand it narrowly as the defense of territory and sovereignty; others understand it more broadly as the defense of national interests. An example of narrow interpretation of defense is the provision of the Polish Constitution, which states that the Armed Forces of the Polish State shall safeguard the independence and integrity of its territory and ensure the security and integrity of its borders. $^{14}$

Meanwhile, many countries with national interests located outside their borders entrust their forces with the task of promoting national interests in places and in the manner specified by their governments. In such cases, the use of the armed forces is based primarily on the need to endorse a country's national interests, rather than to defend its sovereignty and territory. Since states use the term "security" 15 to indicate the preservation of anything they regard as their vital interests, this notion has defensive connotations only in the sense that each nation is prepared to defend those interests against interference by the use of force. Depending on the nature of the security concept, a state's activity may appear to the world at large as either defensive or offensive. However, to the

14 Article 26 of the Constitution of the Republic of Poland of 2 April 1997.

15 Hartmann, The Relations of Nations, 264-265. 
state involved, the actions are ipso facto defensive - that is, defending its vital interests. $^{16}$

We can now resume defining the fundamental nature of military security. It is clear that this is a category which should be directly linked to the understanding of security. Based on a pre-defined understanding of security as the security of the state, it must be recognized that military security is a condition that is variable in time and determines the ability to meet a nation's need to exist and develop, despite the presence of real, or potential, military threats. The concept also includes awareness of the condition in question and all activities aimed at achieving the desired level of security.

It is worth looking at three main components of security (Fig. 3):

- Condition variable in time;

- Awareness of this condition;

- Activity aimed at achieving the desired level of the condition.

Military security also concerns the impact of various countries and other stakeholders as well as environmental factors that affect the military sphere. In turn, this affects the state's ability to meet social needs related to the existence and development of these entities (Fig. 4).

Therefore, military security exists at the time sequence of the states (conditions) resulting from the activity of the subject of security and independently of the changes in activity of the entity's environment of (Fig. 5).

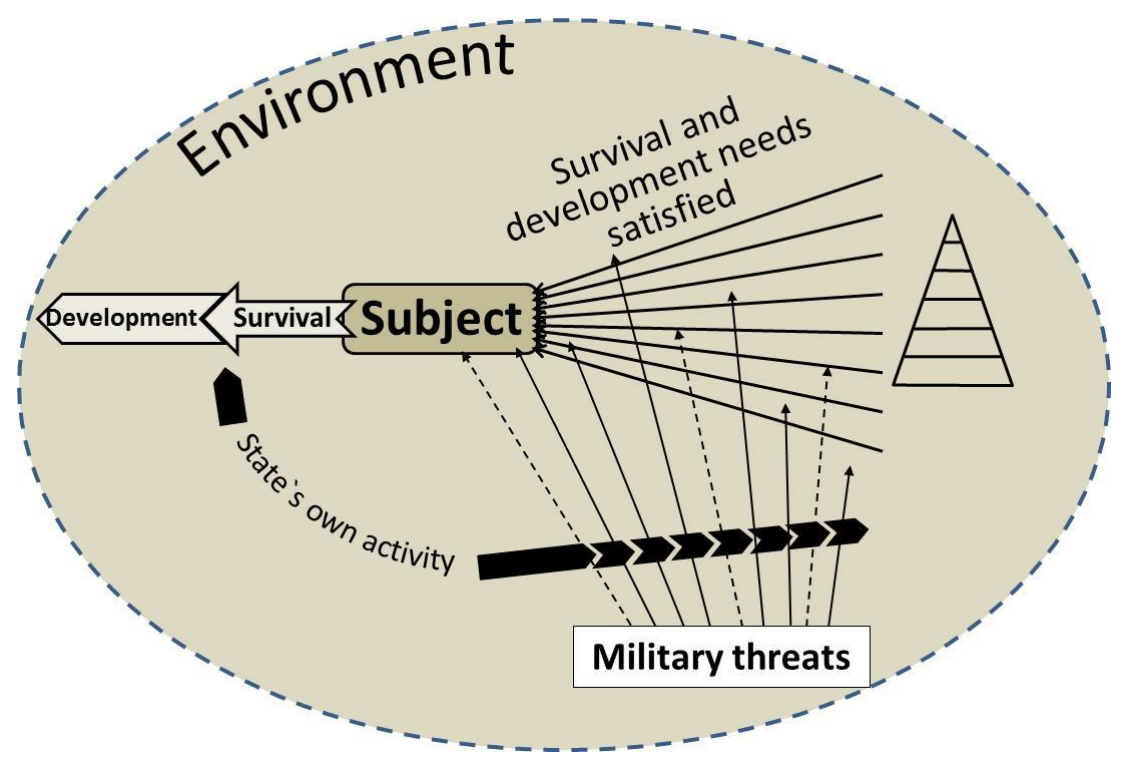

Figure 4: A general model of military security.

16 Ibid. 
The fact that the conditions for military security change and that these changes depend on many factors indicates that security is also a process. Therefore, we can assume that this process can be shaped in the same way as other similar processes. This means that it is necessary to conduct the activity leading to the desired effect. This effect is also the result of factors other than one's own activity. Military security subjects strive to minimize the effects of factors other than their own activity. Usually, subjects seek to actively shape the largest part of their environment that is possible. We can simplify this and assume that the main part of a state's military security is a function of its activity.

Due to the previously described nature of the international environment and, above all, the suspicion and desire of states to secure their own interests, their condition would be worse without action on the part of military security subjects. Therefore, as in the case of living organisms, where a continuous activity of the relevant organs is necessary to sustain life, in the instance of military security continuous activity is required on the part of the subject in order to maintain an acceptable level of security. The purpose of this activity is to maintain the desired level of military security.

This raises the question of the overall shape of the activity system that sustains the desired level of military security. The importance of this question stems from the fact that the structure of the model and its performance have a direct impact on the level of military security.

If the general model of action to achieve security translates into the model of activity aimed at achieving the proper state of military security, we obtain the following (Fig. 6):

- Activity to achieve and maintain military situational awareness;

- Measures to neutralize military threats, especially military attacks.

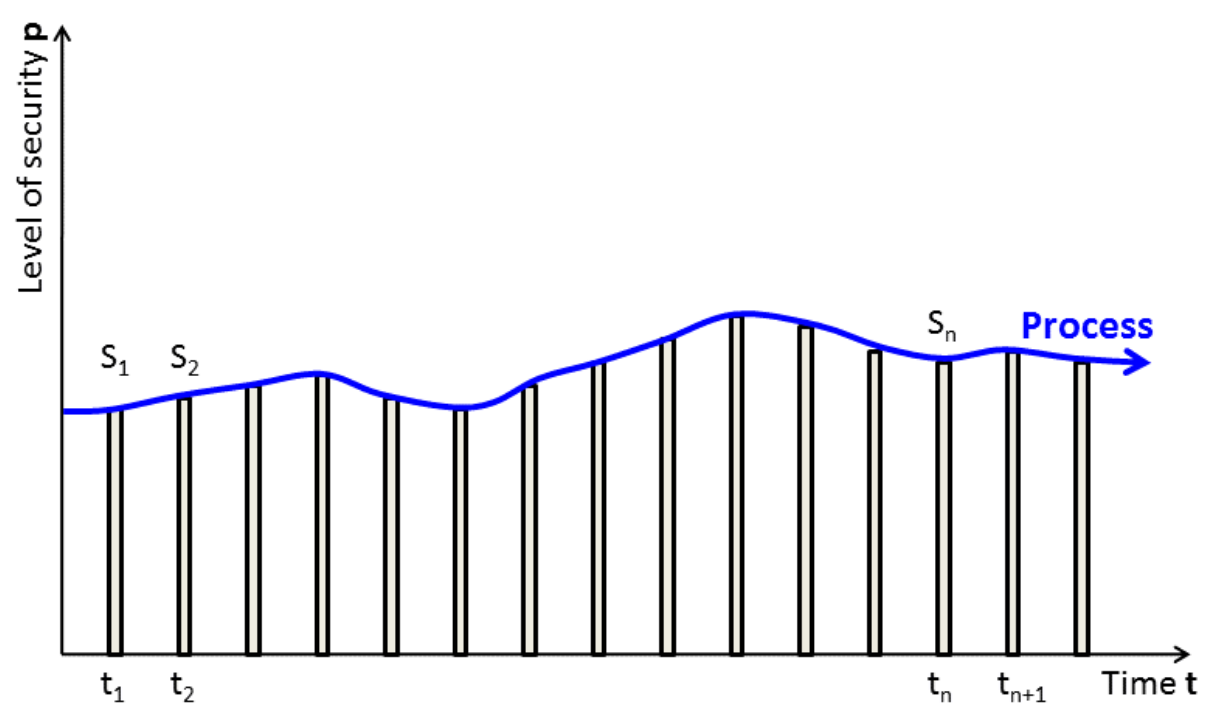

Figure 5: Military security states in time. 


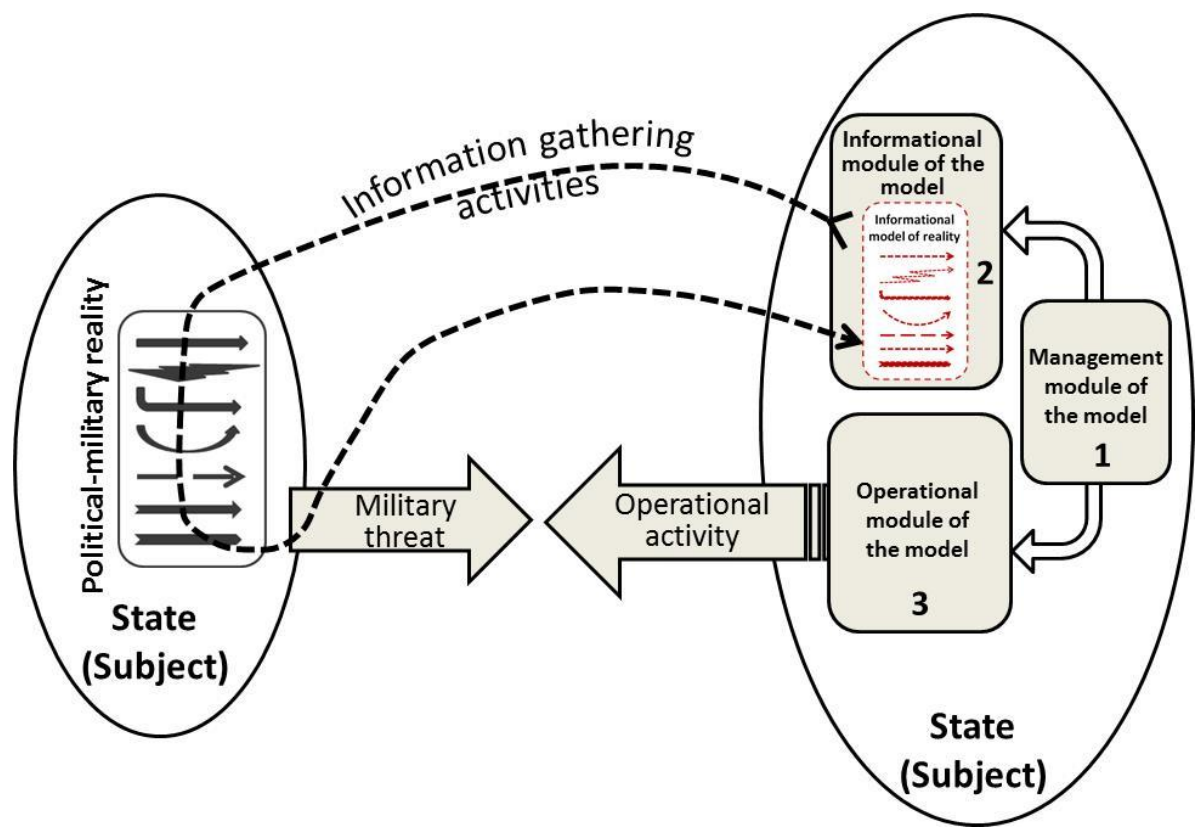

Figure 6: Model of system activities carried out in order to maintain the desired level of military security.

While seeking the elements of such an activity system, it should be noted that the most general models always contain a management module. Its existence depends on the basic assumptions of praxeology or management theory. According to Krzyżanowski, a steering element, as it is widely understood, is an indispensable attribute of any organization. $^{17}$

Therefore, the first essential element of an activity system existing to maintain the desired level of the proper state of military security should be a management module. This module should meet the management functions shaping behavior, which have been widely discussed in literature on this topic.

Activities aiming to prevent military threats must be integrated into the other activities of the state. They should also remain within the limits of applicable national and international law and demonstrate their effectiveness as well as many other features. This activity is typically conducted under various constraints, the most important today being deficiencies and the level of public support for this activity.

From the discussion above we know that the basis of any rational activity is the awareness of the situation in which the subject finds itself. This awareness is essential

17 Leszek J. Krzyżanowski, O podstawach kierowania organizacjami inaczej: paradygmaty, modele, metafory, filozofia, metodologia, dylematy, trendy (Warsaw: PWN, 1999), 32. 
for making reasonable decisions about any actions to be undertaken. Therefore this awareness shapes any decisions that are made, with these directly guiding the activity of the subject. In the case of military security, an important part of this awareness is the knowledge of military threats, particularly of the military capabilities and intentions of the enemy or enemies. This is what F. H. Hartmann calls the circumstances and environmental concerns.

This knowledge is the result of significant efforts undertaken by a state to reveal aspect that its opponent assiduously attempts to conceal, that is, its armed forces' capabilities and intentions. Without this knowledge a state is unable to properly assess military threats and thus, to select appropriate strategies to counter it. Therefore, it should be assumed that one of the main elements of an activity model system that is necessary to maintain the desired level of military security is its information module.

This brings us to another essential element, namely the module of activity used to neutralize military threats. The existence of a management module and a module for acquiring situational awareness enables reliable knowledge of military threats and the environment to be obtained and to make rational decisions on the action needed in response. However, there must be an element of the executive module that enables the designed action to be realized and military threats to be opposed.

The executive sphere in the proposed model reflects the operating module. The module represents the type of activities aimed at countering a detected military threat. Such activity is shaped by a subject's own strategy and the military operations of outside bodies. Therefore, military security is a process in which constant changes take place. These changes are a function of the state's activity in the military field and modifications in a state's environment.

It is worth noting that actors in international relations, both state and non-governmental (non-state) organizations, are to some extent dependent on the surrounding environment. This environment affects their behavior and performance, whereby a state can indirectly influence the actions undertaken by actors in international surroundings. State military activity may, therefore, directly address the various aspects of another country (or a non-state entity) or its surroundings.

The proposal contains a simplified model of an action carried out in order to maintain the desired level of military security, covering its most important elements. While a supply module is of course necessary, it is not unique enough to be included at present. The extracted modules are the core activities of the model and, in practice, should be complemented by elements of service and support. Here, however, the aim is to extract the most relevant elements of military security activity.

\section{Management of Military Security}

The management of military security includes activities that are undertaken to achieve the desired level of security. The proposed model of military security includes two main areas of state activity. One concerns the desired condition of political and military situational awareness and the other aims to prevent military threats. 
With regard to the first sphere of military security, the management activity module should effectively perform the tasks primarily involved in planning and conducting activities for securing a suitable condition of political and military situational awareness.

In the next sphere of activity, the military security management module should fulfill tasks related to planning and conducting activities against military threats. In addition, the management module should also perform a military advisory role to the top management of the state in matters of military security.

\section{Obtaining Situational Awareness of Military Security: the Model's Informa- tional Module}

From the perspective of military security, the aim of the process described above is to achieve an information model in the form of political and military situational awareness (Fig. 7).

In current international literature, situational awareness is defined as having an understanding of what is happing around you. It involves gathering the correct amount of information (all that is needed, but not too much), being able to analyze it and making projections based on this analysis. ${ }^{18}$

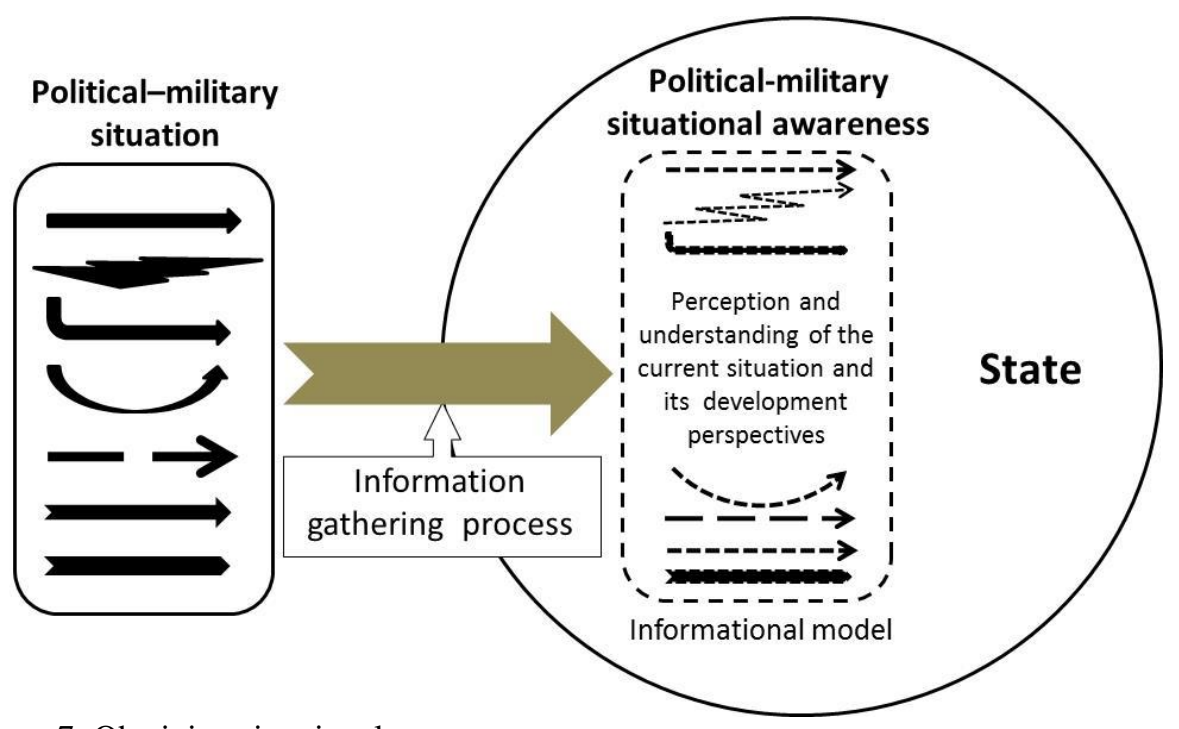

Figure 7: Obtaining situational awareness.

18 Eric S. Toner, "Creating Situational Awareness: A Systems Approach," in Medical Surge Capacity: Workshop Summary (Washington, DC: National Academies Press, 2010), available at http://www.ncbi.nlm.nih.gov/books/NBK32848 (18 July 2014). 
In other terms, it is the perception of the elements in the environment, in time and space, the comprehension of their meaning and the projection of their status in the near future.

Situational awareness must include the following four specific steps:

- Extracting information from the environment;

- Integrating this information with relevant internal knowledge to create a mental picture of the current situation;

- Using this picture to direct further perceptual exploration in a continual perceptual cycle;

- Anticipating future events.

Taking these four steps into account, situational awareness is defined as the continuous extraction of environmental information, the integration of this information with previous knowledge to form a coherent mental picture and the use of that picture in directing further perception and anticipating future events. ${ }^{19}$

Acquiring increasingly better situational awareness means limiting what Carl von Clausewitz has called the "fog of war." The ideal condition would be, of course, full insight into the situation, namely to achieve a condition similar to playing a game of chess. Players see the exact situation or the state of reality that exists in both their own field and that of the opponent. Although they do not have access to the opponent's thoughts, purposes and considerations, they see each of the opponent's moves.

Mica Endsley has distinguished three levels when creating situational awareness (SA) (Fig. 8): $:^{20}$

Perception (Level 1 SA): The first step in achieving situational awareness is to perceive the status, attributes and dynamics of relevant elements in the environment. Thus, Level 1 SA, the most basic level of situational awareness, involves the processes of monitoring, cue detection and simple recognition that lead to the awareness of multiple situational elements (objects, events, people, systems, environmental factors) and their current states (locations, conditions, modes, actions).

Comprehension (Level 2 SA): The next step in situational awareness formation involves a synthesis of disjointed Level $1 \mathrm{SA}$ elements through the processes of pattern recognition, interpretation and evaluation. Level 2 SA requires integrating this information to understand how it will impact upon an individual's goals and objectives. This includes developing a comprehensive picture of the world or of that part of the world that is of interest to the individual.

Projection (Level 3 SA): The third and highest level of situational awareness involves the ability to predict the future actions of the elements in the environment. Level $3 \mathrm{SA}$ is achieved through knowledge of the status and dynamics of the elements and

19 "Situational Awareness," available at www.skybrary.aero/index.php/Situational_Awareness, 23 August 2011.

20 Mica R. Endsley, "Toward a theory of situation awareness in dynamic systems," Human Factors 37, no. 1 (1995): 32-64. 




Figure 8: Situational awareness.

comprehension of the situation (Levels 1 and 2 SA) and by subsequently projecting this information to determine how it will affect future states of the operational environment. $^{21}$

Thus, situational awareness involves the perception and understanding of the current situation as well as its future states. It is formed during the processing of information. It is also worth noting that situational awareness is the cognitive field (domain) of people's minds and includes not only the "knowledge" of information systems, but also the knowledge of commanders and staff personnel, as well as the awareness of this knowledge. ${ }^{22}$ Situational awareness is directly related to another category that includes the situation or set of circumstances in which one finds oneself: the state of affairs as well as the location and surroundings of a place. ${ }^{23}$ It can be assumed that this is an objectively existing part of reality.

These considerations relate to the part of reality called the political and military situation and, therefore, the one that is related to the objective existence of the armed forces in the international environment. The existence of these forces is a source of military threat to the environment in which they exist. As the name suggests, this situation has both political and military components. The political situation, seen in the context of the military, is the part of objectively existing reality that has a political dimension and is related to the armed forces. The military situation is a reality associated with the existence of the armed forces.

Military force is a state's instrument for engaging in international politics. The direct disposal of the forces is within the scope of authority of the state concerned. The armed forces in most countries of the world are players with the ability to use military violence, applied strictly in accordance with the will of the state administrator of these forces. The

21 Endsley, "Toward a theory of situation awareness in dynamic systems."

22 David S.Alberts, "Key Concepts for Information Superiority," Military Technology 32, no. 11 (2008): 75-83.

$23 \mathrm{http} / / /$ oxforddictionaries.com/definition/english/situation?q=situation. 
military is, in fact, an organization whose sole owner is the state. This situation means that the size, quality and capabilities of the armed forces, the forms and methods of their use as well as the direction of their development are determined by the government of that country. Therefore, maintaining up-to-date knowledge of the condition of a military force is just as important as acquiring knowledge of a government's intentions and strategies guiding these forces and keeping this knowledge up to date. Reconnaissance should hence focus on achieving situational awareness related to the activity of both the authorities of the state and the condition of its armed forces as well as the environment that supports them, or on maintaining awareness of the political and military situation.

Understanding the political and military situation corresponds to implementing the first and second step in Endsley's model. A further, important part of this awareness is knowledge of military threats, which is understood as the evaluation of military threats. As previously noted, according to F.H. Hartmann, a state assesses other potentially dangerous countries according to three factors: capability, intent and circumstances. ${ }^{24}$ The examination of the political and military situation is carried out primarily to determine situational awareness, taking into account the aforementioned assumption and the fact that the elements of this situation are military and political ones.

It can be assumed that the basic elements of a military situation are:

- The composition and deployment of the armed forces;

- The state of the armed forces and their supporting infrastructure;

- Factors affecting the armed forces;

- The ongoing processes.

Furthermore, the situation of the armed forces should be seen in the context of the internal (inside the country) and external environment (a state's surroundings). In the internal environment, particular attention should be paid to political directives and supporting infrastructure. The external environment is also important because it is the arena in which these forces may conduct military operations. Furthermore, in this environment various impacts emerge that are directed at the forces acting within it.

In a study of the political situation, the following factors should be particularly taken into account:

- Characteristics of the political culture prevalent in a particular country or nation;

- Characteristics of its dominant worldview, religion and ideology;

- Characteristics of the national interests of the country;

- Characteristics of the security strategy of the country;

- Characteristics of the military strategy of the country;

- Perception of threats to the security of the state;

24 Hartmann, The Relations of Nations, 259-261. 
- Usefulness of military capabilities to secure the national interests of a member state in specific geopolitical and cultural conditions;

- Strategic capabilities of an existing military power in the country;

- Ability to generate military capabilities by the social and economic system of the country;

- Characteristics of the military doctrine of the strategic and operational level;

- Geostrategic characteristics and environmental conditions of the country.

A general model of reconnaissance activities is thus aimed at meeting the informational needs of the military security of the state. This activity is conducted by gathering information in order to obtain political and military awareness and prevent similar activities carried out by the opponents.

The existing need for up-to-date political and military awareness generates the necessity of the continued organization and maintenance of activities connected with finding and refining information processing systems. This requires adequate financial and organizational efforts on behalf of the state. It can be assumed that the basis of military security is to have political and military awareness of the right quality. Often, the significance of this observation is reduced mainly to focusing efforts on buying weapons. However, without the aforementioned awareness, these expenses may, to an extent at least, appear aimless. Reconnaissance efforts, due to the dynamics of the contemporary situation, must be constantly maintained. This is because the adequate early detection of symptoms of increased military threats enables measures to ensure protection against surprise.

Undoubtedly, social development requires meeting the needs of various actors, states and their societies. All subjects operate in an environment containing other bodies. In meeting the needs of the subjects we can identify situations where the needs are similar to those of another subject, or when they are divergent. In accordance with both praxeology and the theory of international relations, meeting these needs is the result of activities that can be carried out under conditions of convergence or a conflict of interest. Depending on the situation, the activity in question takes the form of cooperation or struggle in a broad sense.

In the theory of international relations, interests are a category expressing the needs of a state and they are vital in determining the type of interaction of a state with other states, which can result in either cooperation or struggle. In fact, the activity of a state is a mixture of cooperation and struggle. The relationship between the two factors changes depending on the situation. ${ }^{25}$

Maintaining the desired level of security requires constant activity on the part of the state. This activity is mainly intended to counter a potential or actual military threat and may take a military or non-military form. Both of these may, in turn, take the form of cooperation or struggle (Fig. 9). Non-military activity includes all non-military actions

25 Ryszard Szpyra, Militarne operacje informacyjne (Warsaw: AON, 2003), 44-48. 


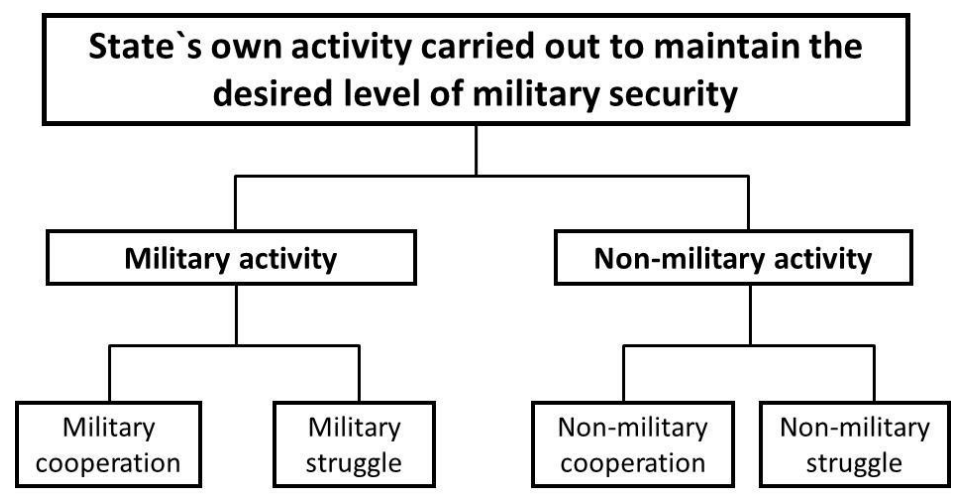

Figure 9: Activities needed to neutralize a threat.

of the state in areas such as economics, finance, culture, etc. Due to the subject matter of the foregoing considerations, the focus of further analysis will be military activity.

If we take time as a criterion for threat-preventing activity, we obtain an action taken before the military attack or after it has begun. The activities carried out in the military sphere before military attacks primarily include deterrence in a broad sense. Its main aim is to prevent the emergence of a military attack. Deterrence does not always prove to be effective, in which case a military attack becomes necessary. Military action should aim to quickly overpower the ongoing attack and restore the pre-attack status.

The activity described above may be portrayed as a general model of the operational activity of a state, carried out to achieve and maintain the desired level of military security (Fig. 10). The main elements of this model are:

- Sources of military threats;

- Subjects of military threats;

- Operational elements to counteract these threats, including:

- Deterrence of possible attacks;

$\circ$ Overpowering of emerging attacks;

- Activities associated with the creation of resistance to eradicate factors of military attacks.

This is obviously a simplified model which nevertheless contains the main components of the phenomenon.

Clearly, the overpowering of attacks materializes after they have begun, however, in order to achieve the effectiveness of the actions described, proper capabilities and systems of activities must be prepared in advance. At the same time, there is a factor of mutual feedback. Having an efficient system of overpowering military attacks is also a strong deterrent in itself. On the surface, maintaining a high-quality system to overpower military attacks during long periods of quiet may seem to be an unnecessary effort, but the lack of attacks itself is precisely the result of sufficiently high defense capabilites. 




Figure 10: General model of operational activity of a state, carried out to achieve and maintain the desired level of military security.

\section{Military Activity of a State Aimed at Achieving the Desired Level of Military Security}

There is a general agreement about the fact that the military component of the state is one of the main instruments of its policy. It is also one of the main elements of what is called the power of a state. The component referred to as the military power of a state is the potential capability of sustained or periodic destruction of elements of another state's organization. It is one of several tools used in different ways in accordance with other tools and forms of activity.

The individual components of state power, including military power on the grounds of its characteristics, have their own patterns of use. However, they can be used independently of each other both in cooperation and struggle. Military power can be applied across a spectrum of activities ranging from extreme forms of struggle to deep cooperation.

Military cooperation may take different forms. Depending on the criterion we adopt, the following forms can be singled out: ad hoc contacts, contracts and international 
agreements, actions in the context of international security organizations and activities carried out within the framework of other international organizations.

Military cooperation is commonly present in international relations and is one of the main ways of improving the military security of many countries. Even major powers, such as the United States, would not be able to maintain the desired level of military security without international military cooperation. This cooperation is necessary and important both in peacetime and during armed conflicts and wars.

\section{Forms of Struggle in the Military Sphere}

In search of possible forms of struggle in the military sphere, one should refer to the disciplines related to military security that are accepted by the scientific community. Undoubtedly, one of these disciplines is international relations. In this discipline, the theory of balance of power, developed by David Hume and perfected by various authors such as Hans J. Morgenthau, still proves valid. In many cases this theory retains full explanatory power. ${ }^{26}$ According to realists, the balance of power is one of the key mechanisms that for centuries have been essential to preserving the freedom of states. ${ }^{27}$

The concept of the balance of power has been interpreted in a number of ways. According to the most general definition thereof, if the survival of a state, or of a few weaker states, threatens the hegemony or a coalition of more powerful states, they should join forces to tie a formal alliance and seek to maintain their independence by balancing the forces of the opposing party. The mechanism of the balance of power is intended to provide a situation in which the forces of the players are aligned, such that they remain in a state of equilibrium. In this case, no state or coalition of states can reach a position in which they can dominate all the others.

Realist and neo-realist theories are the subject of criticism among various representatives of liberalism. Nevertheless, even among them, one can see the effort to modify the forms of implementation of the principle of the balance of power rather than its total denial. This is the point of view of Charles and Clifford Kupchan, who claim that the introduction of the institution of collective security will cause a better balance of power by balancing powers that remain subject to rules and are institutionalized. Such balancing is of greater value than unregulated balancing, which occurs in a state of anarchy. ${ }^{28}$

According to the realist theory of international relations, four techniques have traditionally been used by competing states. ${ }^{29}$ Because these techniques are at the heart of the balance of power, we shall term them the techniques of the balance of power. They are:

26 Thierry de Montbrial, Działanie i system świata (Warsaw: Dialog, 2011), 224.

27 Tim Dunne and Brian C. Schmidt, "Realizm," in Globalizacja polityki światowej. Wprowadzenie do stosunków międzynarodowych, ed. John Baylis and Steve Smith (Krakow: Wydawnictwo Uniwersytetu Jagiellońskiego, 2008), 199-200.

28 John Baylis, "Bezpieczeństwo międzynarodowe i globalne w epoce pozimnowojennej" in Globalizacja polityki światowej. Wprowadzenie do stosunków międzynarodowych, ed. John Baylis and Steve Smith (Krakow: Wydawnictwo Uniwersytetu Jagiellońskiego, 2008), 379.

29 Hartmann, The Relations of Nations, 328. 
1. The acquisition of allies;

2. The acquisition of territories;

3. The establishment of buffer states;

4. The undermining of a potential or actual enemy's strength.

The first two are especially designed to increase absolute strength; the third to allow for the creation (often through neutralization), by mutual consent, of a strategic zone that neither power (or block) can afford to allow the other to occupy; and the fourth to increase one's own relative strength by decreasing the absolute strength of the enemy.

The neutralization of military threats. The worst form of military threat is an armed attack on a state. Whatever the nature of the attack, it usually has either strategic implications such as loss of territory, blocking the ability to secure vital national interests, and the total or partial loss of sovereignty, or it causes significant costs that set back the state's development for many years. Therefore, the primary objective of neutralizing military threats is the prevention of military attacks and the use of armed violence. The desired form of such prevention is deterrence which, when effectively carried out, prevents an armed attack from materializing.

However, deterrence is not always effective and may lead to an armed attack on a state. Due to the importance of the security of the state, it must maintain an effective system of neutralizing potential military attacks in keeping with its capabilities. The essence of such a system should be the ability to directly stop, or paralyze, a launched military attack as early as possible and to restore the status from the time before the attack. Paralyzing attacks primarily means conducting effective defense. It can take many forms, such as maneuvering or positional defense. It may also take the form of air defense, antimissile, sea or even cyber defense.

It is desirable to have the military capabilities to conduct strategic attacks because these could force the enemy to cease its own attacks. The basis for obtaining effectiveness in overpowering an opponent's military attacks are deliberately developed, prepared capabilities. These capabilities should ensure effective deterrence and military action against surprises, namely overpowering military attacks.

Deterrence. According to the Encyclopedia Britannica, deterrence is military strategy by which one power uses the threat of reprisal to effectively preclude an attack from an adversary. ${ }^{30}$

According to Thomas Schelling, deterrence is a threat aimed to stop the enemy from doing something. ${ }^{31}$ The author clearly distinguishes deterrence from compellence, which he defines as a threat aimed to provoke the enemy into action. Similarly, Glenn Snyder says that deterrence is the strength of dissuading as opposed to the forces of coercion. $^{32}$ Moreover, John Mearsheimer explains that deterrence, in its broadest sense,

${ }^{30}$ http://www.britannica.com/EBchecked/topic/159558/deterrence (18 June 2014).

31 Thomas C. Schelling, Arms and Influence (New Haven: Yale University Press, 1967), 69.

32 Glenn H. Snyder, "Deterrence and Defense," in The Use of Force: Military Power and International Politics, eds. Robert J. Art and Kenneth N. Waltz (New York: University Press of America, 1988), 31. 
means persuading the enemy not to take any action because the perceived benefits do not justify the estimated costs and risks. ${ }^{33}$ Another well-known theorist, Colin Gray, believes that deterrence happens when a person, institution or policymakers decide not to take actions that would otherwise be performed. ${ }^{34}$ Such a failure to act is based on their belief or deep suspicion concerning unacceptable consequences resulting from the possible adoption of the abandoned actions.

\section{Military Activity of a State Aimed at Paralyzing Armed Attacks}

The military security of states, understood as their security in relation to military threats, is achieved by, inter alia, the establishment and maintenance of an effective system of operation that is capable of paralyzing armed attacks. The system of such actions is called the defense system of a state. Its basic elements are:

- Steering system;

- Executive element, paralyzing armed attacks;

- Supply module;

- Shaped environment.

The steering system primarily comprises political authorities supported by the appropriate military institutions. The executive element of the defense system consists of the armed forces supported by various paramilitary forces. To carry out its work, the executive element needs information, materials and an energy supply. Most of the executive element's needs are catered to by the state. The development of the environment, understood primarily as military engineering, also has a significant impact on the military capabilities of states.

Strategies are important elements of these systems and there are many different strategies for defense. They can be divided into:

- Strategies not accepting temporary losses;

- Strategies accepting such a possibility.

The former strategies are positional defense strategies, i.e. those that do not allow for temporary losses or acquisition of specific targets (e.g. territorial gains) by the attacking forces. The latter rely on the gradual weakening of the attacking forces and the temporary loss of certain targets to the enemy. These activities, designed and conducted to neutralize any military attacks, are called actions against military surprise. The essence of such activities comes down to preventing the enemy from reaching its potential or actual objectives.

33 John J. Mearsheimer, Conventional Deterrence (Ithaca: Cornell University Press, 1983), 14.

34 Colin S. Gray, "Deterrence and the Nature of Strategy," in Deterrence in the 21st Century, ed. Max G. Manwaring (London: Frank Cass, 2001), 18. 


\section{Activity of a State Aimed at Improving the Protection of its Organization and Infrastructure}

State activity in the field of countering military threats should also take the form of improving the protection of the organization and infrastructure of the state. It can be carried out either in the absence of a crisis or during its existence and take the form of, for example, critical infrastructure protection, which immunizes objects against different types of attacks. Such activities include, inter alia, the construction of shelters for civilians, equipment and other ancillary facilities. One of the measures in this group of activities is also the development of information security systems.

The authors of the monograph "Polish National security in the twenty-first century. Challenges and Strategies," draw attention to yet another aspect of this broader issue. ${ }^{35}$ They argue that creating widespread territorial defense is of fundamental importance in ensuring the effective defense of critical infrastructure. One of the main functions of this type of defense is to protect and defend the important areas and facilities throughout Poland in cooperation with civil services, guards and NGOs. Widespread territorial defense provides an opportunity to ensure the effective protection of critical infrastructure by the military organization of a society in order to defend its patrimony, of which the critical infrastructure is an essential element.

\section{Conclusion}

The basic premise of this study is that the key assumptions and the conceptual system of military security must result from the conceptual system of security studies. Since both disciplines are relatively young, there is a need to analyze them for the purpose of determining the basic conceptual apparatus in the field of the security studies. As in any discipline, and in this one in particular, there is a plurality of concepts that compete with each other in a "free market" and clash in scientific debates. It was necessary, therefore, to find one that meets the needs of this study. Since none of them were fully satisfactory, it was necessary to analyze many of them and synthesize their major components.

The proposed model contains an original definition and description of the fundamental nature of security as well as a general description of military security. It includes the vital domain of the subject's own activity leading to the maintenance of the proper level of security.

Undoubtedly, such content is based on theories presented in the aforementioned fields of research, but these serve merely as "bricks" that are used to fill in the already existing theoretical structure. Thus, through a specific redesign, a structure compatible with the basic tenets of security studies has been devised, also taking into account recent results of other sciences that cover military affairs.

35 Bezpieczeństwo narodowe Polski w XXI wieku. Wyzwania i strategie (Warsaw: Bellona, 2006), 356. 


\section{Bibliography}

Baylis, John. "Bezpieczeństwo międzynarodowe i globalne w epoce pozimnowojennej." In Globalizacja polityki światowej. Wprowadzenie do stosunków międzynarodowych, 379. Krakow: Wydawnictwo Uniwersytetu Jagiellońskiego, 2008.

Bezpieczeństwo narodowe Polski w XXI wieku. Wyzwania i strategie. Warsaw: Bellona, 2006.

Constitution of the Republic of Poland., 1997.

de Montbrial, Thierry. Działanie i system świata. Warsaw: Dialog, 2011.

Department of Defense Dictionary of Military and Associated Terms. Washington, D.C.: Department of Defense, 2008.

Dunne, Tim, and Brian C. Schmidt. "Realizm." In Globalizacja polityki światowej. Wprowadzenie do stosunków międzynarodowych, 199-200. Krakow: Wydawnictwo Uniwersytetu Jagiellońskiego, 2008.

Endsley, Mica R.. "Toward a Theory of Situation Awareness in Dynamic Systems." Human Factors (1995).

Gray, Colin S.. "Deterrence and the Nature of Strategy." In Deterrence in the 21st Century, 18. London: Frank Cass, 2001.

Hartmann, Frederick H.. The Relations of Nations. New York: Macmillan, 1978.

Krzyżanowski, Leszek J.. $O$ podstawach kierowania organizacjami inaczej: paradygmaty, modele, metafory, filozofia, metodologia, dylematy, trendy. Warsaw: PWN, 1999.

Longman Dictionary of Contemporary English. New Edition. Warsaw: PWN, 1990.

Mearsheimer, John J.. Conventional Deterrence. Ithaca: Cornell University Press, 1983.

Paleri, Prabhakaran. National Security: Imperatives And Challenges. New Delhi: Tata McGraw-Hill, 2008.

Power, Nina. "Philosophy's Subjects." PARRHESIA: A Journal of Critical Philosophy 3 (2007): 56 and 69.

S.Alberts, David. "Key Concepts for Information Superiority." Military Technology 32, no. 11 (2008): 75-83.

Schelling, Thomas C.. Arms and Influence. New Haven: Yale University Press, 1967.

Situational Awareness., 2011.

Snyder, Glenn H.. "Deterrence and Defense." In The Use of Force: Military Power and International Politics, 31. New York: University Press of America, 1988. 
Szpyra, Ryszard. Militarne operacje informacyjne. Warsaw: AON, 2003.

Toner, Eric S.. "Creating Situational Awareness: A Systems Approach." In Medical Surge Capacity: Workshop Summary. Washington, DC: National Academies Press, 2010.

Uniwersalny słownik języka polskiego A-J. Warsaw: PNW, 2006.

Williams, Paul D.. Security Studies: An Introduction. New York: Routledge, 2009.

Zięba, Ryszard. "Pojęcie $i$ istota bezpieczeństwa międzynarodowego." In Bezpieczeństwo międzynarodowe po zimnej wojnie, 16. Warsaw: WaiP, 2008.

Zięba, Ryszard. Instytucjonalizacja bezpieczeństwa europejskiego. Koncepcje struktury - funkcjonowanie. Warsaw: Scholar, 1999. 